\title{
PROFIL STRATEGI BELAJAR DAN DAMPAKNYA TERHADAP PENCAPAIAN HASIL BELAJAR BAHASA INDONESIA SISWA SEKOLAH DASAR
}

\author{
Dyah Werdiningsih \\ Fakultas Keguruan dan Ilmu Pendidikan Universitas Islam Malang \\ email: dyahwerdi@yahoo.co.id
}

\begin{abstract}
This study aims to investigate the profile of the Indonesian language learning strategies that elementary school students use in terms of types, intercorrelations, and effects on learning outcomes. This was a correlational study. The data were analyzed using the descriptive statistics to obtain the means representing the learning strategies and the inferential statistics consisting of the correlation to find out the intercorrelations of learning strategy categories and the linear regression to find out contributions of learning strategies to learning outcomes. The results show that: (1) the six learning strategies are frequently used with a mean of $3.69,(2)$ they are significantly interrelated, and (3) they give significant contributions to the language mastery attainment with F 4.552 ( $p<.000)$.
\end{abstract}

Keywords: learning strategies, types of learning strategies, intercorrelations

\section{PENDAHULUAN}

Kajian strategi belajar bahasa merupakan salah satu kajian proses pemerolehan bahasa. Kajian ini menarik dilakukan seiring dengan bergesernya orientasi pengkajian pemerolehan bahasa. Pada mulanya pengkajian pemerolehan bahasa terfokus pada apa yang telah dikuasai pembelajar bahasa yang merupakan kajian hasil pemerolehan bahasa. Selanjutnya, kajian ini diperluas pada kajian bagaimana pembelajar mendapatkan bahasa yang merupakan kajian tentang proses pemerolehan bahasa.

Strategi belajar digunakan pembelajar untuk mencapai tujuan tertentu dan terwujud dalam berbagai jenis. Penggunaan strategi belajar ini tampak pada tindakan-tindakan atau perilakuperilaku khusus yang dilakukan pembelajar untuk meningkatkan kemampuan bahasanya, misalnya dengan cara meniru, mengulang-ulang, mentransfer ke dalam bahasa lain, memperbaiki tuturan, meminta klarifikasi, dan lain-lain.
Sebagai contoh, pembelajar melakukan pengulangan-pengulangan karena ada sesuatu yang harus diingat bagaimana penggunaannya. Tindakan-tindakan ini dapat diamati dalam perilaku berbahasa anak pada saat berinteraksi dengan mitra tuturnya. Menurut Oxford (1990) perilaku tersebut dipengaruhi oleh beberapa karakteristik umum, seperti perkembangan usia, kemampuan bahasa, kondisi psikologis pembelajar bahasa.

Banyak faktor dipandang berpengaruh terhadap keberhasilan belajar bahasa baik bersifat situasional (seperti konteks belajar, sarana belajar, ketersediaan guru yang profesional, dan lainlain) maupun yang bersifat individual (seperti intelegensi, bakat bahasa, usia, motivasi belajar, kepribadian, dan lainlain). Namun demikian, Thomson dan Rubin (1982) menegaskan, "You, the language learners, are the most important factor in the language learning process. Many learners tend to blame teachers, circumstances, and teaching materials for their lack 
of success, when the most important reasons for their success or failure can ultimately be found in themselves". Pernyataan ini menunjukkan bahwa pembelajar sendirilah yang sangat menentukan keberhasilan belajarnya.

Salah satu aspek dalam diri pembelajar adalah strategi belajar (learning strategy) yang diterapkan. Sadtono (1995) memprediksi bahwa siswa Indonesia yang gagal dalam belajar bahasa Inggris tidak menerapkan strategi belajar yang efektif. Dia menyatakan mereka itu "do not realise that learning a foreign language requires perseverance, discipline, knowledge of techniques of assimilating new habits, self-evaluation, a great deal of practice and that the whole business takes a long time".

Penelitian di bidang strategi belajar bahasa kedua/asing ini muncul pada pertengahan 1970-an setelah Stern (1975) yang membuat daftar sepuluh strategi yang menurutnya dipakai oleh good language learners. Strategi tersebut adalah: (1) planning strategy, yaitu bahwa pembelajar yang baik berusaha mencari gaya belajar yang tepat bagi dirinya, (2) active strategy, yaitu bahwa pemblajar yang baik berusaha melibatkan diri secara aktif pada kegiatan belajar bahasa, (3) empathic strategy, yaitu bahwa pembelajar yang baik mengembangkan sikap empati terhadap penutur asli bahasa yang dipelajari, (4) formal strategy, yaitu bahwa pembelajar yang baik berusaha menguasai pengetahun tentang aturan kebahasaan bahasa yang dipelajari, (5) experimental strategy, yaitu bahwa pembelajar yang baik senantiasa membuat hipotesis-hipotesis tentang penggunaan bahasa dan bereksperimen untuk menguji hipotesisnya tersebut, (6) semantic strategy, yaitu bahwa pembelajar yang baik senantiasa memperhatikan makna atas ujaran yang dibuatnya serta ujaran orang lain, (7) practice strategy, yaitu bahwa pembelajar yang baik senantiasa mempraktikkan bentuk ba- hasa yang dipelajari, (8) communication strategy, yaitu bahwa pembelajar yang baik menggunakan bahasa yang dipelajari dalam berkomunikasi, (9) monitoring strategy, yaitu bahwa pembelajar yang baik memonitor perkembangan belajarnya, dan (10) internalization strategy, yaitu bahwa pembelajar yang baik berusaha berfikir dalam bahasa target, bukan bahasa pertamanya. Daftar ini dijadikan acuan oleh Rubin (1975) saat meneliti karakteristik good language learners dan menghasilkan temuan bahwa pembelajar yang baik itu (1) are accurate guesser (2) have a strong drive to communicate, (3) are often not inhibited, (4) prepared to attend to form, (5) practice, (6) monitor their speech, dan (7) attend to meaning. Penelitian lebih lanjut oleh Willing (1988) juga menghasilkan daftar strategi belajar yang digunakan oleh pembelajar bahasa kedua antara lain valueing, planning, evaluating, monitoring, internalizing, hypothesizing, rehearsing, communicating, persisting, risktaking, practicing, inferencing, attending to meaning, attending to form, dan absorbing.

Pada tahun 1980-an penelitian tentang strategi belajar tidak hanya melibatkan pembelajar yang dipandang sebagai good language learners saja, melainkan semua pembelajar. Chamot dan Küpper (1989) mendapatkan temuan bahwa strategi belajar yang dipakai pembelajar bahasa bisa dikelompokkan ke dalam tiga kategori, yaitu (1) strategi kognitif, yaitu langkah-langkah yang diambil dalam pemecahan masalah yang menuntut analisis dan sintesis secara langsung atas materi belajar, (2) strategi metakognitif, yaitu strategi dalam mengelola kegiatan belajar bahasa, dan (3) strategi sosial/afektif, yaitu strategi dalam meningkatkan interaksi dengan penutur asli bahasa target. Beberapa strategi yang termasuk dalam strategi kognitif antara lain repetition, translation, deduction, dan note-taking. Sementara itu, yang termasuk strategi metakognitif 
antara lain advance organizers, directed attention, selective attention, dan selfmonitoring, sedangkan yang termasuk strategi sosial/afektif adalah cooperation dan questions for clarification.

Penelitian tentang strategi belajar ini semakin berkembang pada tahun 1990-an. Oxford (1990) mengklasifikasi strategi belajar menjadi dua kategori umum, yaitu direct strategies dan indirect strategies. Strategi belajar dikatakan direct jika dalam penerapannya melibatkan penggunaan bahasa target secara langsung dan strategi belajar dikatakan indirect jika dalam penerapannya tidak berkenaan secara langsung dengan penggunakan bahasa target. Direct strategies terdiri dari tiga kategori strategi, yaitu strategi memory, cognitive, dan compensation. Sedangkan indirect strategies juga terdiri dari tiga kategori, yaitu strategi metacognitive, affective, dan social. Selanjutnya Oxford mengembangkan kuesioner untuk mengukur penggunaan keenam kategori strategi belajar yang bersifat apriori tersebut yang disebut Strategy Inventory for Language Learning (selanjutnya disingkat SILL). Ellis (1994: 539) menyatakan bahwa pengorganisasian strategi-strategi khusus ke dalam hirarki tingkatan dan luasnya taxonomi yang dikembangkan oleh Oxford sangat impresif. Oleh karena itu, banyak penelitian di dunia yang menggunakan SILL ini sebagai alat pengumpul datanya. Penelitian ini pun juga menggunakan SILL sebagai landasan awal dalam pengembangan instrumen penelitiannya.

Sebagaimana dijelaskan di muka, walaupun penelitian tentang strategi belajar ini telah dimulai pada tahun 1970an di negara-negara barat, penelitian dengan topik ini baru dimulai akhir tahun 1990an di Indonesia. Lengkanawati (1997) meneliti penggunaan strategi belajar oleh 114 mahasiswa jurusan Pendidikan Bahasa Inggris IKIP Bandung.
Dengan menggunakan modifikasi SILL dan TOEFL sebagai pengumpul data, peneliti menemukan bahwa mahasiswa menggunakan strategi memori dan strategi sosial pada tingkat yang rendah sedangkan strategi kognitif, kompensasi, metakognitif, dan afektif digunakan dengan intensitas yang tinggi. Dalam hal ini strategi yang intensitas penggunaannya paling rendah adalah strategi memori dan yang paling tinggi adalah strategi kompensasi. Temuan ini cukup mengejutkan karena selama ini dicurigai bahwa penggunaan strategi memori oleh pembelajar di Asia sangat tinggi (LoCastro, 1995; Politzer \& McGroarty, 1985). Kejutan lain dalam penelitian ini adalah bahwa analisis korelasi ganda atas keenam kategori strategi belajar dengan skor TOEFL menghasilkan nilai F 0,911 yang mengindikasikan tidak adanya korelasi yang signifikan.

Penelitian lain tentang strategi belajar dilakukan oleh Djiwandono (1998) memfokuskan prediktabilitas kemampuan komunikasi dari strategi belajar pada mahasiswa di Universitas Widya Karya Malang. Penelitian ini menyimpulkan bahwa dari ketiga aspek penggunaan strategi belajar keragaman (diversity), keajegan (consistency), dan kejelasan tujuan (purposefulness), hanya diversity yang berkorelasi terhadap kemahiran komunikasi. Lebih mencengangkan lagi, Huda (1998) meneliti pada mahasiswa jurusan Pendidikan Bahasa Inggris di IKIP Malang dan menemukan bahwa pembelajar yang mempunyai prestasi belajar yang bagus justru mempunyai strategi belajar yang lebih sedikit dari pada pembelajar dengan prestasi yang biasa saja. Dalam hal ini tujuh puluh jenis strategi belajar diidentifikasi dari kelompok pertama dan hanya lima puluh jenis strategi yang terindentifikasi dari kelompok kedua. Penelitian tersebut dilanjutkan oleh Mistar (2001a, 2001b, 2006) dan Setyadi (1999 
dan 2004). Penelitian-penelitian yang dilakukan di Indonesia ini menempatkan variabel strategi belajar sebagai prediktor atas keberhasilan belajar dan hampir semuanya menggunakan subjek pembelajar bahasa Inggris di tingkat perguruan tinggi.

Selama beberapa tahun terkahir, penelitian tentang strategi belajar telah menjadi payung penelitian di Fakultas Keguruan dan Ilmu Pendidikan (FKIP) Universitas Negeri Malang. Secara operasional penelitian tentang strategi belajar tersebut mencakup penelitian dosen maupun penelitian skripsi, tesis, maupun disertasi. Penelitian-penelitian professional dosen terdiri atas beberapa penelitian program ARU (Anggaran Rutin Universitas), PTK, RUKK, Fundamental, dan lain-lain. Beberapa penelitian tentang strategi belajar tersebut, diantaranya dipaparkan sebagai berikut.

Penelitian oleh Mistar (2001a) pada mahasiswa jurusan bahasa Inggris kependidikan di Universitas Islam Malang, bahasa Inggris nonkependidikan di Universitas Gajayana Malang dan mahasiswa yang belajar bahasa Inggris sebagai mata kuliah minor di Politeknik Malang menunjukkan bahwa faktorfaktor individual yang berupa anxiousness about language learning dan attitude and learning orientation merupakan dua faktor yang berpengaruh terhadap penggunaan strategi belajar, sementara language aptitude dan personality traits tidak berpengaruh terhadap penggunaan strategi belajar. Peneliti ini juga melaporkan bahwa pada mahasiswa di ketiga lembaga pendidikan tinggi tersebut, strategi metakognitif digunakan dengan intensitas yang paling tinggi dan strategi kompensasi digunakan dengan intensitas paling rendah (2001b). Selanjutnya Mistar (2006) melaporkan bahwa dari dua belas kategori strategi hasil analisis faktor delapan di antaranya berpengaruh terhadap kemahiran ber- bahasa yang diukur dengan melakukan self-rating. Kedua belas kategori strategi tersebut adalah (1) strategies for active use of English, (2) metacognitive, analytic strategies, (3) affective and social strategies, (4) memory strategies, (5) compensation and anxiety management in speaking, (6) memory and formal practice strategies, (7) cognitive and compensation strategies in reading, dan (8) visual memory and anxiety management strategies.

Dari paparan tersebut, dapat disimpulkan bahwa pengetahuan mengenai profil penggunaan strategi belajar oleh pembelajar dari berbagai tingkatan belajar masih sangat diperlukan untuk mengidentifikasi strategi belajar apa saja yang dipandang efektif dan banyak digunakan oleh pembelajar yang selanjutnya bisa dikembangkan model pengembangan strategi belajar yang dapat bermanfaat untuk membekali pembelajar bahasa agar dapat menguasai bahasa target yang ingin dikuasainya secara efektif. Pengembangan model pengembangan strategi belajar ini sejalan dengan pernyataan Nunan (1995) dan Oxford (1990) bahwa pembelajar bahasa tidak hanya diberi pembelajaran untuk menguasai bahasa tetapi perlu diberi pembelajaran bagaimana strategi untuk menguasai bahasa dengan baik. Untuk mengetahui efektivitas model pengembangan strategi belajar yang telah dikembangkan, diperlukan penelitian lebih lanjut dalam bentuk penelitian tindakan kelas atau penelitian eksperimental.

Penelitian yang diusulkan ini juga merupakan kelanjutan dari kegiatan yang masih tercakup dalam payung penelitian yang telah disebutkan. Melalui berbagai kajian bidang ini, diharapkan dapat dihasilkan temuan-temuan tentang karakteristik tipe-tipe strategi belajar yang digunakan siswa, perkembangan strategi belajar yang digunakan siswa, yang pada akhirnya dapat digu- 
nakan untuk mengembangan teori-teori belajar bahasa yang bermanfaat untuk meningkatkan kualitas pembelajaran bahasa di berbagai jenjang pendidikan.

Tim peneliti juga berencana dapat mengembangkan model-model pengembangan strategi belajar yang dapat mendukung efektivitas pencapaian kompetensi komunikasi berbahasa Indonesia siswa sesuai dengan dengan wilayah sekolah (desa maupun kota), dan status sekolah (bermutu rendah, sedang, dan tinggi. Di samping itu, diupayakan dapat menerbitkan bukubuku penunjang pembelajaran bahasa Indonesia yang berkarakteristik memberdayakan strategi belajar siswa dalam berbagai jenjang pendidikan sesuai dengan perkembangan emosi, kognisi, dan sosial mereka.

Sejalan dengan uraian tersebut, penelitian ini difokuskan pada tiga hal, yakni penyusunan profil strategi belajar yang digunakan pembelajar di sekolah dasar (SD), pengembangan model pengembangan strategi belajar untuk mendukung efektivitas proses penguasaan kompetensi komunikatif siswa, dan uji efektivitas model pengembangan strategi belajar tersebut. Penyusunan profil strategi belajar yang digunakan oleh pembelajar dari berbagai tingkatan jenjang pendidikan itu akan sangat bermanfaat untuk mengidentifikasi strategi belajar apa saja yang dipandang efektif dan banyak digunakan oleh pembelajar. Selanjutnya, temuan ini dapat dijadikan sebagai dasar untuk mengembangkan model pengembangan strategi belajar untuk mendukung pencapaian kompetensi dasar yang ditargetkan. Model yang telah tersusun, lebih lanjut akan diuji efektivitasnya dengan penelitian tindakan kelas atau penelitian eksperimental

Secara umum penelitian ini bertujuan untuk mengkaji profil penggunaan strategi belajar bahasa Indonesia siswa SD yakni (1) mengkaji tipe-tipe strategi belajar bahasa Indonesia oleh pembelajar di SD, (2) mengkaji interkorelasi antarstrategi belajar yang digunakan oleh siswa SD, dan (3) mengkaji pengaruh penggunaan strategi belajar terhadap hasil belajar bahasa Indonesia siswa SD kelas $1 \mathrm{~s} / \mathrm{d} 6$.

\section{METODE PENELITIAN}

Penelitian ini menggunakan pendekatan kuantitatif. Oleh karena itu, data yang dikumpulkan senantiasa akan berupa angka atau dinyatakan dalam bentuk angka dan analisis data akan dilakukan dengan menggunakan prosedur analisis statistik.

Dalam penelitian ini digunakan kombinasi desain deskriptif, korelasional, dan ex-post facto. Desain deskriptif akan dipakai untuk mencapai tujuan penelitian yang berkaitan dengan penyusunan profil penggunaan strategi belajar bahasa Indonesia. Korelasional digunakan untuk mengkaji hubungan antara penggunaan strategi belajar yang satu dengan strategi yang lain. Adapun desain ex-post facto digunakan untuk mencapai tujuan-tujuan yang berkenaan dengan pengaruh penggunaan strategi belajar terhadap hasil belajar siswa.

Populasi dalam penelitian ini adalah semua siswa SD di kota dan Kabupaten Malang. Agar penelitian ini menjadi lebih manageable, peneliti akan melakukan penyampelan dengan menerapkan teknik cluster sampling yang berjenjang. Dalam hal ini wilayah kota dan kabupaten Malang akan dibagi masing-masing menjadi lima kluster wilayah. Dari masing-masing kluster akan dipilih 1 SD sebagai wakil dari masing-masing kluster.

Instrumen utama yang akan dipakai dalam penelitian ini berupa kuesioner yang mengukur penggunaan strategi belajar. Kuesioner akan disusun akan menggunakan bentuk skala 
Likert (Likert-scale) dengan mengacu pada teori yang telah ada dengan rujukan utama pada klasifikasi apriori yang dikembangkan oleh Oxford (1990) dan O'Malley dan Chamot (1990). Dengan demikian, pada tahap awal kuesioner akan disusun berdasarkan klasifikasi strategi memori, kognitif, kompensasi, metakognitif, afektif, dan sosial. Bentuk kuesioner ini adalah yang terstruktur (structured questionnaire) yang berisi ternyataan tentang butir-butir strategi belajar. Subjek akan diminta menilai dirinya tentang tingkat penggunaan strategi tersebut dalam belajar bahasa Indonesia dengan memilih salah satu dari beberapa alternatif yang disediakan, seperti tidak pernah, jarang, kadang-kadang, sering, dan selalu.

Sebelum dipergunakan untuk pengumpulan data penelitian, kuesioner yang tersusun akan dianalisis kualitasnya, terutama dari aspek validitas dan reliabilitasnya. Di antara berbagai macam validitas, validitas konstruk merupakan hal yang harus terpenuhi dalam instrumen ini. Oleh karena itu, instrumen yang dikembangkan akan diujicobakan terlebih dahulu kepada subjek populasi yang tidak terpilih sebagai sampel dan analisis akan dilakukan dengan mengkorelasikan data pada masing-masing butir kuesioner dengan data pada keseluruhan kuesioner. Butirbutir kuesioner yang mempunyai korelasi positif yang tidak signifikan atau mempunyai korelasi yang negatif akan dibuang karena butir-butir tersebut dipandang tidak memberi kontribusi yang berarti pada pengukuran trait yang akan diukur. Selanjutnya, reliabilitas internal dari kuesioner ini akan diukur melalui Cronbach Alpha dan syarat minimal 0,80 harus dipenuhi sebagai syarat reliabilitas.

Setelah sampel penelitian ditetapkan dan instrumen pengumpul data telah dibuktikan memenuhi syarat validi- tas dan reliabilitas, peneliti melakukan pengambilan data. Dalam hal ini peneliti akan mengurus perijinan melalui Kantor Dinas Pendidikan kota Malang. Dengan berbekal ijin tersebut peneliti akan datang ke sekolah-sekolah yang menjadi sampel penelitian. Siswa yang ada dalam kelas sampel akan diminta mengisi surat kesediaan menjadi subjek penelitian. Hal ini perlu dilakukan karena keterlibatan siswa dalam penelitian ini harus bersifat suka rela. Siswa yang telah menandatangani surat kesedian menjadi subjek penelitian itu akan diminta untuk mengisi kuesioner tentang strategi belajar bahasa Indonesia. Pengisian kuesioner ini akan memerlukan waktu sekitar 30 menit.

Sebelum menghasilkan sebuah perangkat data yang siap dianalisis secara statistik, kertas kerja subjek yang berupa kuesioner akan dikuantifikasi dengan menggunakan skala skor $1-5$ atas intensitas penggunaan strategi belajar yang dipajankan. Dalam hal ini skor 1, 2, 3, 4, dan 5 digunakan untuk rentangan intensitas tidak pernah, jarang, kadang-kadang, sering, dan sering sekali. Data kuantitatif yang terkumpul ini akan dipakai untuk melakukan klasifikasi atas strategi belajar secara posteriori melalui analisis faktor.

Oleh karena itu, sebelum analisis faktor dilakukan, terlebih dahulu akan dilihat apakah data memenuhi tiga syarat penggunaan analisis faktor (Pallant, 2001). Syarat-syarat tersebut adalah (1) matriks korelasi antar strategi belajar tersebut harus mengandung koefisien korelasi yang lebih dari 0,3, (2) hasil test of sphericity dengan menggunakan Bartlett's test harus signifikan, dan (3) ukuran kecukupan sampling yang dilakukan dengan Keise-Meyer-Oklin harus mencapai minimal 0,6.

Jika ketiga syarat di atas terpenuhi, maka analisis faktor akan dilakukan dengan menggunakan Principal 
Component Analysis (PCA). Jumlah faktor yang dihasilkan akan dijadikan sebagai dasar dalam menentukan jumlah kategori strategi belajar. Untuk itu masing-masing faktor akan diberi nama kategori strategi belajar yang berbedabeda tergantung pada butir strategi mana saja yang mempunyai loading yang tinggi dengan batasan $\pm 0,3$. Untuk itu, maka component matrix yang dihasilkan dari analisis faktor akan dirotasikan dengan menggunakan teknik Varimax with Keiser Normalization Method untuk mengidentifikasi butir strategi mana yang mempunyai loading yang tinggi pada faktor tertentu.

Setelah kategori strategi belajar terbentuk, disusunlah profil penggunaan masing-masing strategi dengan tingkat pemakaian sebagai berikut: (1) rendah bila rata-rata penggunaan antara 1 hingga 2,44; (2) sedang bila rata-rata penggunaan antara 2,45-3,44; (3) tinggi bila rata-rata penggunaan antara 3,45 - 5,00 (Oxford, 1990). Selanjutnya penggunaan masing-masing strategi belajar itu dkorelasikan satu sama lain untuk mengukur interkorelasinaya. Hanya koefisien korelasi yang signifikan pada taraf signifikasi kurang dari 5\% saja yang dianggap signifikan. Untuk mengetahui pengaruh penggunaan strategi belajar terhadap hasil belajar bahasa Indonesia siswa SD digunakan analisis regresi linier.

\section{HASIL PENELITIAN DAN PEMBA- HASAN}

Berdasarkan hasil penelitian, pada bagian ini dipaparkan tentang beberapa hal sebagai berikut (1) tipe-tipe strategi belajar siswa SD, (2) interkorelasi antarstrategi belajar siswa SD, dan (3) efek penggunaan strategi belajar terhadap hasil belajar siswa SD.

\section{Tipe-tipe Strategi Belajar Siswa SD}

Untuk menjawab pertanyaan tentang bagaimanakan tipe-tipe strategi belajar yang digunakan siswa SD, peneliti mengumpulkan data dengan teknik penyebaran angket kepada sejumlah siswa yang menjadi sampel penelitian ini. Dari keenam kategori strategi belajar, dilakukan analisis tentang tingkat intensitas penggunaan strategi belajar tersebut dengan melihat tingkat penggunaannya pada masing-masing kategori strategi belajar. Temuan tentang tingkat intensitas pemakaian ini disajikan pada tabel 1 .

Tabel 1: Intensitas Penggunaan Strategi Belajar

\begin{tabular}{lccc}
\hline \multicolumn{1}{c}{ Strategi Kategori } & Mean & $\begin{array}{c}\text { Intensitas } \\
\text { Penggunaan }\end{array}$ & Rangking \\
\hline Strategi memori & 3.54 & tinggi & 5 \\
Strategi kognitif & 3.77 & tinggi & 3 \\
Strategi kompensasi & 3.43 & sedang & 6 \\
Strategi afektif & 3.79 & tinggi & 2 \\
Strategi metakognitif & 3.61 & tinggi & 4 \\
Strategi sosial & 3.99 & tinggi & 1 \\
\hline
\end{tabular}

Tabel 1 menunjukkan bahwa secara umum pembelajar bahasa Indonesia di tingkat SD menggunakan strategi belajar pada tingkat tinggi dengan ratarata penggunaan sebesar 3,69. 
Analisis terhadap penggunaan strategi belajar pada masing-masing kategori didapatkan temuan bahwa satu kategori strategi belajar dipergunakan dengan tingkat intensitas yang sedang, selebihnya lima kategori strategi belajar dipergunakan pada tingkat yang tinggi. Kategori strategi belajar yang dipergunakan dengan intensitas yang sedang adalah strategi kompensasi. Hal ini menandakan bahwa dalam aktivitas belajar bahasa Indonesia pembelajar Indonesia di tingkat SD kurang terfokus pada aspek terjaganya kelancaran komunikasi.

Dari keenam kategori strategi belajar yang ditemukan, jenis strategi belajar yang paling intensif penggunaannya adalah strategi sosial 3.99 dan yang paling rendah intensitas penggunaannya adalah strategi kompensasi dengan intensitas penggunaan yang 3,43. Ini menunjukkan bahwa pembelajar bahasa Indonesia di SD masih kurang memperhatikan upaya-upaya untuk menjaga kelancaran komunikasi. Pembelajar siswa SD cenderung menggunakan strategi sosial. Strategi ini terdiri atas tiga tipe, yaitu (a) pertanyaan, yang meliputi pertanyaan untuk verifikasi dan pertanyaan untuk koreksi; (b) kerjasama, yang meliputi kerjasama dengan teman sebaya dan kerjasama dengan ahli; dan (c) empati terhadap orang lain, yang meliputi pemahaman budaya dan pemahaman terhadap perasaan orang lain. Hal ini sejalan dengan prinsip bahwa tujuan akhir dalam setiap pembelajar bahasa seharusnya lebih pada pencapaian kemampuan menggunakan bahasa tersebut dalam berkomunikasi baik tulis maupun lisan, dan bukan pada pencapaian nilai semata. Nyikos and Oxford (1993) menyatakan bahwa, "learners in communicative competence oriented context prefer strategies that involve active use of the target language, while learners in grade oriented context exhibit more strategies that deal with formal, rule-related processing strategies".

Dalam penelitian ini diperoleh temuan bahwa pembelajar bahasa Indonesia tingkat SD di Indonesia merupakan pengguna strategi belajar pada tingkat moderat dengan nilai rata-rata penggunaan 3,69. Temuan ini sejalan dengan temuan-temuan yang lain yang dilakukan di negara-negara lain. LoCastro (1994) melaporkan bahwa pembelajar bahasa Indonesia di Jepang juga menggunakan strategi belajar dengan tingkat intensitas yang sedang saja dengan nilai rata-rata intensitas penggunaan strategi belajar yang sama pada mahasiswa Korea yang sedang belajar bahasa Indonesia, dengan nilai rata-rata pemakaian antara 2,91 dan 3.5. Keadaan yang sama juga didapatkan pada mahasiswa di India (Shorey, 1999). Penggunaan strategi belajar dengan intensitas yang tinggi didapatkan di Australia, yaitu pada siswa di Adult Migrant Education Service (AMES) Australia, yang belajar bahasa Indonesia sebagai bahasa kedua. Temuan ini menunjukkan bahwa sosial strategies merupakan strategi yang intensitas penggunaannya sangat tinggi (mean=3.12) Lunt, 2000). Dalam konteks pembelajaran bahasa selain bahasa Inggris, Oxford, Park-Oh, Ito and Sumrall (1993) menemukan bahwa pembelajar Amerika yang belajar bahasa Jepang melalui program satelit juga menerapkan strategi belajar pada tingkat yang medium. Pada penelitian nilai intensitas penggunaan strategi belajar merentang antara 2,54 untuk strategi strategi dan 3,02 untuk strategi kognitif. Pembelajar bahasa Jepang dan bahasa Perancis di perguruan tinggi Singapura pun juga ditemukan merupakan pengguna strategi belajar bahasa dengan intensitas yang sedang dengan nilai rata-rata intensitas penggunaan sebesar 2,93 (Warton, 2000).

Dilihat dari aspek intensitas penggunaan masing-masing strategi, 
penelitian ini menemukan bahwa strategi sosial digunakan dengan intensitas yang paling tinggi, sementara strategi kompensasi dipergunakan dengan intensitas yang paling rendah. Ini menandakan bahwa dalam upaya belajar dan menggunakan bahasa Indonesia, pembelajar Indonesia lebih mementingkan kesiapan mental psikologis dalam belajar daripada aspek-aspek lain seperti ketepatan gramatika, ketetapan pelafalan, dan sebagainya. Temuan ini juga menunjukkan diperlukannya pelatihanpelatihan dalam mengatasi kendalakendala komunikasi yang disebabkan oleh keterbatasan kemampuan berbahasa mereka. Hal ini sejalan dengan paling rendahnya intensitas penggunaan strategi kompensasi oleh pembelajar Indonesia tingkat SD.

\section{Interkorelasi Antarstrategi Belajar Siswa SD}

Berdasarkan temuan penelitian ini diketahui bahwa tingkat intensitas penggunaan strategi belajar siswa SD antarstrategi belajar rata-rata pada tingkat penggunaan yang tinggi. Selanjutnya, hasil analisis interkorelasi di antara keenam jenis strategi belajar tersebut menunjukkan bahwa intensitas penggunaannya saling berkorelasi satu sama lain. Interkorelasi keenam strategi belajar yang digunakan oleh siswa SD kelas 1 s/d 6 dipaparkan pada tabel 2.

Tabel 2: Interkorelasi Diantara 6 Strategi Belajar

\begin{tabular}{lllllll}
\hline & Memori & Kognitif & Kompen & Afekif & Metakog & Sosial \\
\hline Memori & 1.000 & & & & & \\
Kognitif & $\left..290^{* *}\right)$ & 1.000 & & & & \\
Kompen & $.344\left(^{* *}\right)$ & $.459\left(^{* *}\right)$ & 1.000 & & & \\
Afektif & $.288\left(^{* *}\right)$ & $\left..653^{* *}\right)$ & $.421\left(^{* *}\right)$ & 1.000 & & \\
Metakog & $\left..133^{*}\right)$ & $.38\left(^{* *}\right)$ & $.410\left(^{* *}\right)$ & $.450\left(^{* *}\right)$ & 1.000 & \\
Sosial & $\left..260^{* *}\right)$ & $\left..411^{* *}\right)$ & $.37\left(^{* *}\right)$ & $\left..487^{* *}\right)$ & $.555\left(^{* *}\right)$ & 1.000 \\
\hline${ }^{* *}$ P<0.01 & & & & & &
\end{tabular}

Berdasarkan paparan tersebut, korelasi tinggi diperoleh antara strategi (1) afektif dan kognitif ( $\mathrm{r}=.653$, $\mathrm{p}<.01)$, (2) kompensasi dan kognitif $(\mathrm{r}=.459, \mathrm{p}<.01),(3)$ afektif dan kompensasi $(\mathrm{r}=.421, \mathrm{p}<.01)$, (4) metakognitif dan afektif $(\mathrm{r}=.450, \mathrm{p}<.01)$, (5) metakognitif dan kompensasi $(\mathrm{r}=.410, \mathrm{p}<.01)$, (6) sosial dan kognitif $(\mathrm{r}=.411, \mathrm{p}<.01),(7)$ sosial dan afektif $(\mathrm{r}=.487, \mathrm{p}<.01)$, (8) sosial dan metakognitif $(\mathrm{r}=.555, \mathrm{p}<.01)$, (9) metakognitif dan kognitif $(\mathrm{r}=.384, \mathrm{p}<.01),(10)$ sosial dan kompensasi $(\mathrm{r}=.370, \mathrm{p}<.01)$. Sementara korelasi yang sedang diperoleh antara strategi kompensasi dan memori $(\mathrm{r}=.344, \mathrm{p}<.01)$. Adapun korelasi yang rendah diperoleh antara (1) kognitif dan memori $(r=.290, p<.01)$, (2) afektif dan memori ( $\mathrm{r}=.288, \mathrm{p}<.01)$, (3) metakognitif dan memori $(\mathrm{r}=.133, \mathrm{p}<.01)$, dan (4) sosial dan memori $(r=.260, p<.01)$.

Berdasarkan uraian tersebut diketahui bahwa walaupun koefisien korelasi itu berada pada makna kekuatan yang berbeda, semua koefisien korelasi yang ada menunjukkan tingkat yang signifikan pada tingkat 0,01 (2-tailed test). Ini mengandung arti bahwa peningkatan pada intensitas penggunaan salah satu kategori strategi belajar bahwa Indonesia akan selalu diikuti oleh peningkatan serupa pada intensitas penggunaan 
strategi yang lain.

Penelitian ini mendapatkan bahwa intensitas penggunaan keenam strategi belajar itu saling berkorelasi secara signifikan. Hal ini berarti bahwa setiap perubahan dalam penggunaan suatu jenis strategi belajar akan diikuti pula oleh perubahan penggunaan strategi yang lain. Oxford dan Erhman (1995), Park (1997) dan Mistar (2001 dan 2009) juga melaporkan hal yang sama. Temuan ini mempunyai implikasi yang kuat terhadap pelatihan penggunaan strategi belajar. Penyelenggara pelatihan bisa berharap bahwa pelatihan yang berfokus pada salah satu jenis strategi belajar akan mempunyai efek samping pada peningkatan intensitas penggunaan strategi yang lain. Selanjutnya, jika pembelajar telah mencapai tingkat penggunaan strategi belajar secara efektif, mereka akan menjadi pembelajar yang otonom, yaitu mereka akan bertanggung jawab atas kegiatan belajarnya sendiri (Holec, 1981).

Hubungan yang dekat antara strategi belajar dan kemandirian (otonomi) pembelajar ini juga ditekankan oleh Wenden and Rubin (1987), yang menyatakan bahwa, one of the goals of the research on foreign language learning strategies is to promote learner autonomy. Sementara itu, Little (1997) sebagaimana dikutip oleh Harris (1997, p.9) juga menekankan hubungan antara strategi belajar dan kemandirian pembelajar dalam pernyataannya sebagai berikut: If the pursuit of learner autonomy requires that we focus explicitly on the strategic component of language learning and language use, the reverse should also be the case: focus on strategies should lead us to learner autonomy.

\section{Efek Penggunaan Strategi Belajar ter- hadap Hasil Belajar Siswa SD}

Untuk mengukur pengaruh penggunaan strategi belajar terhadap pencapaian kemahiran berbahasa Indonesia pada pembelajar tingkat SD dilakukan analisis regresi standar. Hasil analisis ini diringkas pada tabel 3 dengan menggunakan kombinasi keenam kategori strategi belajar sebagai variabel bebas dan nilai perolehan tes ujian tengah semester genap 2009/2010 sebagai variabel terikatnya.

\section{Tabel 3: Hasil Analisis Regresi}

Dependent Variabel: Nilai Siswa

\begin{tabular}{lclccc}
\cline { 3 - 5 } Multiple R & 0.737 & \multicolumn{4}{c}{ ANOVA } \\
\cline { 3 - 6 } R Square & 0.543 & & $\mathrm{df}$ & $\begin{array}{c}\text { Sum of } \\
\text { Squares }\end{array}$ & Mean Square \\
\cline { 3 - 6 } Adjusted $\mathrm{R}$ & & & & & \\
Square & 0.424 & Regression & 6 & 1665.146 & 277.524 \\
Std. Error & 7.808 & $\begin{array}{l}\text { Residual } \\
\text { Total }\end{array}$ & 17 & 1402.354 & 60.972 \\
\cline { 3 - 6 } & & \multicolumn{2}{r}{$\mathrm{F}=4.552$} & 3067.500 & \multicolumn{2}{c}{ Significance F $=.004$} \\
\hline
\end{tabular}

Hasil analisis regresi menunjukkan bahwa kombinasi keenam strategi pembelajaran merupakan prediktor yang signifikan terhadap hasil belajar dengan nilai $\mathrm{F}$ hitung sebesar 4.552 $(\mathrm{p}<.000)$. Nilai total variansi ukuran 
nilai yang dijelaskan oleh strategi belajar ini masing-masing adalah sebesar (1) $43.8 \%$ untuk strategi memori, (2) $26,4 \%$ untuk strategi kognitif, (3) 74,8\% untuk strategi kompensasi, (4) 54,8\% untuk strategi afektif, (5) 50,4\% untuk strategi metakognitif, dan (6) 30\% untuk untuk sosial.

Terkait dengan pengaruh strategi belajar terhadap capaian kemahiran berbahasa Indonesia yang diukur dengan tes hasil belajar akhir semester genap 2009/2010, secara umum penelitian ini mendukung proposisi yang menyatakan bahwa the learners choice off learning strategies both in type and quantity determines learning outcomes, which may be measured in terms of learning rate, levels of achievement or proficiency (Ellis, 1994).

Temuan penelitian ini berimplikasi pada beberapa hal. Pertama adalah guru-guru SD perlu memahami bahwa penggunaan bahasa adalah suatu bentuk perilaku sosial, dan bahasa adalah komunikasi. Oleh karena itu mempelajari bahasa secara otomatis akan melibatkan orang lain. Dengan demikian strategi sosial menjadi sangat penting dalam proses ini. Tiga tipe strategi sosial yang perlu dilatihkan kepada siswa adalah bertanya, bekerjasama dengan orang lain, dan berempati dengan orang lain. Dengan bertanya siswa dapat terbantu pemahaman mereka, mendorong rekan mereka untuk menanggapi percakapannya, dan menunjukkan minat dan keterlibatan mereka dalam belajar. Penggunaan strategi bekerjasama dapat menghindarkan kompetisi dan menumbuhkan semangat kelompok. Penggunaan strategi ini dapat mendorong saling ketergantungan positif dan dukungan timbal balik antarpembelajar bahasa Indonesia. Dengan demikian penggunaan strategi kooperatif secara konsisten dapat memberikan dampak yang sifnifikan untuk (1) menumbuhkan harga diri dan kepercayaan diri, (2) meningkatkan rasa senang dalam belajar, (3) menghindarkan rasa egoisme, dan (4) meningkatkan saling perhatian satu sama lain. Adapun penggunaan empati dapat meningkatkan kemampuan mereka untuk meletakkan diri siswa pada orang lain agar lebih memahami perspektif orang tersebut. Dengan berempati siswa dapat mengembangkan pemahaman kultural dan berhati-hati terhadap pemikiran dan perasaan orang lain.

Sejalan dengan hal tersebut, siswa perlu diberi banyak waktu untuk mempraktikkan penggunaan bahasa Indonesia di sekolah dalam bentuk interaksi komunikatif yang sesungguhnya. Pembentukan kelompok-kelompok diskusi/ percakapan, kelompok membaca (reading group), dan lain-lain adalah beberapa contoh forum-forum yang memungkinkan siswa terlibat dalam kegiatan yang menggunakan bahasa Indonesia sebagai alat komunikasi dengan melibatkan pembelajar lain. Meminta siswa untuk senantiasa menggunakan bahasa Indonesia saat berkomunikasi dengan guru di luar kelas juga merupakan salah satu cara untuk meningkatkan peluang siswa menggunakan bahasa Indonesia dalam komunikasi (Oxford, 1990).

Implikasi yang kedua adalah bahwa siswa harus dibuat sadar atas pentingnya menggunakan berbagai ragam strategi belajar secara intensif karena strategi belajar tersebut berpengaruh secara signifikan terhadap capaian kemahiran berbahasa Indonesianya. Semakin banyak dan semakin intensif mereka menggunakan strategi belajar, semakin bagus pula capaian kemahiran berbahasanya. Pelatihan strategi belajar yang terintegrasi dengan kegiatan pembelajaran merupakan pendekatan yang terbaik dalam melakukan pelatihan strategi belajar (strategy training). 


\section{SIMPULAN}

Berdasarkan hasil analisis data disimpulkan beberapa hal sebagai berikut. Pertama, dari enam kategori strategi belajar siswa SD rata-rata digunakan dengan tingkat intensitas yang tinggi, yakni 3.69. Jenis strategi belajar yang paling intensif penggunaannya adalah strategi sosial 3.99 dan yang paling rendah intensitas penggunaannya adalah strategi kompensasi dengan intensitas penggunaan yang 3,43. Ini menunjukkan bahwa pembelajar bahasa Indonesia di SD masih kurang memperhatikan upaya-upaya untuk melibatkan pembelajar lain untuk mencapai kemahiran berbahasa mereka. Dengan demikian siswa SD cenderung menggunakan strategi sosial. Strategi ini terdiri atas tiga tipe, yaitu (a) pertanyaan, yang meliputi pertanyaan untuk verifikasi dan pertanyaan untuk koreksi; (b) kerjasama, yang meliputi kerjasama dengan teman sebaya dan kerjasama dengan ahli; dan (c) empati terhadap orang lain, yang meliputi pemahaman budaya dan pemahaman terhadap perasaan orang lain.

Kedua, hasil analisis interkorelasi keenam jenis strategi belajar yang digunakan siswa SD menunjukkan bahwa penggunaan keenam strategi belajar tersebut saling berkorelasi satu sama lain secara signifikan. Hal ini menunjukkan peningkatan dalam intensitas penggunaan suatu strategi belajar cenderung akan diikuti peningkatan juga pada intensitas penggunaan strategi yang lain.

Ketiga, penggunaan strategi belajar ini diketahui berpengaruh secara signifikan terhadap capaian kemahiran berbahasa yang diukur dengan tes Ujian Tengan Semester Genap 2009/2010. Hasil analisis regresi menunjukkan bahwa kombinasi keenam strategi pembelajaran merupakan prediktor yang signifikan terhadap hasil belajar dengan nilai F hitung sebesar 4.552 ( $\mathrm{p}<.000)$.

\section{DAFTAR PUSTAKA}

Djiwandono, P. I. 1998. The Relationship between EFL Learning Strategies, Degree of Extroversion, and Oral Communication Proficiency: a study of second year secretarial students at Widya Karya University. Unpublished Doctoral thesis, IKIP MALANG Indonesia.

Ehrman, M. \& Oxford, R. 1990. Adult Language Learning Styles and Strategies an an Intensive Training Setting. The Modern Language Journal 74(iii), 311-327.

Harris, V. 1997. Teaching Learners How to Learn: strategy training in the $M L$ classroom. London: Centre for Information on Language Teaching and Reserch.

Holec, H. 1981. Autonomy and Foreign Language Learning. Strasbourg: Council of Europe.

Huda, N. 1998. Speaking Proficiency, Reflectivity-Impulsivity, and L2 Learning Strategies. In W. A. Renandya \&G. M. Jacobs (Eds), Learners and Language Learning: RELC Anthology Series 39 (pp. 4055). Singapore: SEAMEO Regional Language Centre.

Lengkanawati, N. S. 1997. Kontribusi Strategi Belajar Bahasa terhadap Kemahiran Berbahasa. Tesis. Tidak diterbitkan IKIP BANDUNG.

LoCastro, v. 1994. Learning Strategies and Learning Environments. TESOL Quarterly 28(2), 409-414.

Lunt, E. H. 2000. The Learning Strategies of Adult Immigrant Learners of English: Quantitative and Qualitative Perspectives. Unpublished PhD thesis, The University of Melbourne.

Mistar, J. 2001. English Learning Strategies of Indonesian University Students Across Individual Differences. Asian journal of English Language Teaching. 11, 19-44. 
Mistar, J. 2000. The Effect of Learning Strategies on Perceived English Proficiency. Jurnal Pendidikan dan Pembelajaran Fakultas Keguruan dan Ilmu Pendidikan Universitas Lampung 4 (1), 25-36.

Nyikos, M. \& Oxford, R. 1993. A Factor Analytic Study Of LanguageLearning Strategy Use: Interpretations From Information-Processing Theory And Social Psychology. The Modern Language Journal 77(i), 11-22.

O'Malley, J. M. \& Chamot, A. U. 1990 Learning Strategies in Second Language Acquisition. Cambridge: Cambridge University Press.

Oxford, R. L. 1990. Language Learning Strategies: What Every Teacher Should Know. New York: Newbury House Publishers.

Oxford, R. L. 1993. Research on Second Language Learning Strategies. Annual Review of Applied Linguistics 13, 175-187.

Oxford, R. \& Nyikos, M. (1989). Variables Affecting Choice of Language Learning Strategies by University Students. The Modern Language Journal 73(iii), 291-300.

Oxford, R. Park-Oh, Y. Ito, S. \& Sumrall, M. 1993. Japanese by Satellite: Effects of Motivation, Language Learning Styles and Strategies, Gender, Course Level, and Previous Language Learning Experience on Japanese Language Achievement. Foreign Language Annals 26(3), 359-371.

Oxford, R. L. \& Ehman, M. E. 1995. Adults' Language Learning Strategies in an Intensive Foreign Language Program in the United States, System 23(3), 359-386.

Pallant, J. F. 2001. SPSS Survival Manual: a Sstep-by-Step Guide to Data Analysis Using SPSS. Crows Nest, NSW: Allen \& Unwin.
Park, G. 1997. Language Learning Strategies and English Proficiency in Korean University Students. Foreign Language Annals 30(2), 211221.

Politzer, R. L. \& McGroarty, M. 1985. An Exploratory Study of Learning Behaviors and Their Relationship to Gains in Linguistic and Communicative Competence, TESOL Quarterly 19(1), 103-124.

Rubin, J. 1975. What the "Good Language Learner" Can Teach Us. TESOL Quarterly 9(1), 41-51.

Rubin, J. \& Thomson, I. 1982. How to Be a More Successful Language Learner. Bostom: Heinle \& Heinle Publishers, Inc.

Sadtono, E. 1995. Perspektif Pengajaran Bahasa Indonesia di Indonesia. Malang: FPBS IKIP MALANG.

Sheorey, R. 1999. An Examination of Language Learning Strategy Use in the Setting of an Indigenized Variety of English. System 27(2), 173-190.

Stern, H. H. 1975. What Can We Learn from the Good Language Learner? Canadian Modern Language Review 31(3), 304-318.

Thompson, I. \& Rubin, J. 1996. Can Strategy Instruction Improve Listening Comprehension. Foreign Language Annals 29(3), 331-342.

Wenden, A. 1991. Learner Strategies for Learner Autonomy. London: Prentice-Hall International Ltd.

Wenden, A. \& Rubin, J. (Eds). 1987. Learner Strategies in Language Learning. London: Prentice-Hall International Ltd.

Wharton, G. 2000. Language Learning Strategy Use of Bilingual Foreign Language Learners In Singapore. Language Learning 50(2), 203-243. 